\title{
Ecosystem based business model of a smart grid
}

\author{
M. Lundgaard, Z. Ma \& B. N. Jørgensen \\ Maersk McKinney Moeller Institute, Denmark
}

\begin{abstract}
This paper investigates an ecosystem based business model in a smart grid infrastructure and the potential of value capture in a highly complex macro infrastructure such as a smart grid. It proposes an alternative perspective in studying the smart grid business ecosystem to support infrastructural challenges, such as the interoperability of business components for a smart grid. So far, little research has explored the business ecosystem in the smart grid concept. A study on a smart grid with the theory of business ecosystem may open opportunities to understand market catalysts. This study contributes towards an understanding of a business ecosystem applicable for a smart grid. Smart grid infrastructure is an intricate business ecosystem, which has several intentions to deliver the value proposition and what it should be. The findings help to identify and capture value from markets.

Keywords: smart grid, business ecosystem, smart grid infrastructure, business modeling.
\end{abstract}

\section{Introduction}

A smart grid is a primary focus for society due to increasing energy consumption. Many existing smart grid solutions have been discussed as electricity grids worldwide remain outdated and inefficient [1]. Sustainable and smart energy is a hot topic all over the world with many new initiatives announced every year. To solve the issues of discontinuous energy sources and production [2], several smart grid initiatives have been proposed to create a new infrastructure and technology for energy and information flow, which can optimize the entire energy sector from generation to consumption by end-users. 
This paper aims to investigate the propositions of an ecosystem based business model of a smart grid. An ecosystem based business model approach implies an understanding of markets, organization, stakeholders and the network between them $[3,4]$. This paper adopts this approach with a case study to create business models and implementation opportunities for the rural micro grids in the sub-Saharan Africa. The results provide a potential solution for companies to develop a sustainable ecosystem based business model in the sub-Saharan African smart grid market. The case study demonstrates the business ecosystem prospective of integrating a smart grid into the existing business model of the focal company. Such market entry strategies have been applied for many products, but there are few examples of the infrastructural products or service such as a smart grid.

\section{Literature review}

\subsection{Smart grid}

The Organization for Economic Co-operation and Development (OECD) defines smart grid by the functions and components with ICT at the centre of the system [5]. This differentiates a smart grid from a general product as a smart grid is both a product and an infrastructure of information. Smart grid proposes a system with two-way communication infrastructure of information and energy flows, which allows control of distributed generation, storage, consumption and flexible demand [6]. A similar definition by Xenias et al. [7] describes that smart grid is the communication between electricity producers and users through ICT to manage demand and response. The infrastructure of smart grid is a crucial and intricate system of information exchange through the electricity value chain. The smart grid infrastructure is not only dependent on the technological components but also the characteristics or 'patterns of social practices and thinking' by a socio-technical perspective [6]. Smart grid has to utilize different means of generation, transmission connections and smart distributed consumption to uphold a functioning system.

\subsection{Business ecosystem}

The ecosystem is a community whereby each organization and individual interacts to form a business organism including suppliers, producers, competitors and other stakeholders each contributing to the value of goods and services [3]. The stakeholders are dependent on mutually shared competences and supporting roles. Smart grid depends highly on an infrastructural business with many technology providers, political influence and suppliers. It makes the smart grid a complex ecosystem due to the high amount and diversity of stakeholders.

According to Galateanu and Avasilcai [8], there are four main ecosystems: the biological, digital business, industrial and social ecosystem. Smart grid systems combine the digital business ecosystem and industrial ecosystem. The digital ecosystem aspect is due to the digital network in the complex 
infrastructure of information technologies. This is integrated with the sociotechnical aspect of business ecosystems [9]. The industrial ecosystem focuses on sustainable development which is an awareness of the ecological issues of the industrial processes [8]. There are several articles that discuss the business ecosystem with different aspects (shown in Table 1):

Table 1: Applied secondary data of business ecosystem models.

\begin{tabular}{|c|c|c|c|}
\hline Article & $\begin{array}{l}\text { Business } \\
\text { Ecosystem }\end{array}$ & Significance & Requirements \\
\hline$[10]$ & $\begin{array}{l}\text { Framework of } \\
\text { financial, } \\
\text { strategic, } \\
\text { customer and } \\
\text { business } \\
\text { components. }\end{array}$ & $\begin{array}{l}\text { Comparative tools } \\
\text { to determine } \\
\text { ecosystem } \\
\text { configuration and } \\
\text { strategy. }\end{array}$ & $\begin{array}{l}\text { Ecosystem inside } \\
\text { knowledge. } \\
\text { Factors of markets } \\
\text { and business model. }\end{array}$ \\
\hline [3] & $\begin{array}{l}\text { Ecosystem } \\
\text { model } \\
\text { definition. }\end{array}$ & $\begin{array}{l}\text { Stakeholder } \\
\text { identification and } \\
\text { business ecosystem } \\
\text { defining. }\end{array}$ & $\begin{array}{l}\text { Core activities in the } \\
\text { business. } \\
\text { Network analysis } \\
\text { and leadership } \\
\text { identification. }\end{array}$ \\
\hline [4] & $\begin{array}{l}\text { Ecosystem } \\
\text { strategy. }\end{array}$ & $\begin{array}{l}\text { Strategy } \\
\text { development } \\
\text { within ecosystem } \\
\text { principles and } \\
\text { understanding the } \\
\text { role in the } \\
\text { ecosystem. }\end{array}$ & $\begin{array}{l}\text { Internal ecosystem } \\
\text { knowledge. }\end{array}$ \\
\hline [8] & $\begin{array}{l}\text { Ecosystem } \\
\text { architecture. }\end{array}$ & $\begin{array}{l}\text { Interconnectivity of } \\
\text { ecosystem } \\
\text { architectures. }\end{array}$ & $\begin{array}{l}\text { Organizational } \\
\text { interface knowledge } \\
\text { How components of } \\
\text { the ecosystem } \\
\text { interacts. }\end{array}$ \\
\hline
\end{tabular}

Relationship complexity is important for understanding the positioning of focal companies in an ecosystem. The interrelation of a smart grid infrastructure is highly complex due to regulation and standards. It requires companies to put an effort in the ecosystem relationship and interactions. Focal companies need to determine their strategies relative to the ecosystem [4].

An ecosystem is a strategic tool for understanding value creation, and extends the value chain $[4,11]$. The business ecosystem enables stakeholders to generate value, which could not be obtained by a single firm [12]. Lansiti and Levien [4] develop the ecosystem's network capabilities and network value based on this principle. Lansiti and Levien [4] propose a matrix to determine companies' strategic ecology (shown in figure 1). Weiller and Neely [10] propose business 
modeling in an ecosystem context. Their framework (figure 1) is based on the electronic vehicle (EV) markets, and it also can be applicable for similar industries. The model is based on theories of business model innovation to capture value [13]. This model tool conceptualizes companies' capabilities in an ecosystem. The framework visualizes the consequences of each dimension change to the ecosystem factors.

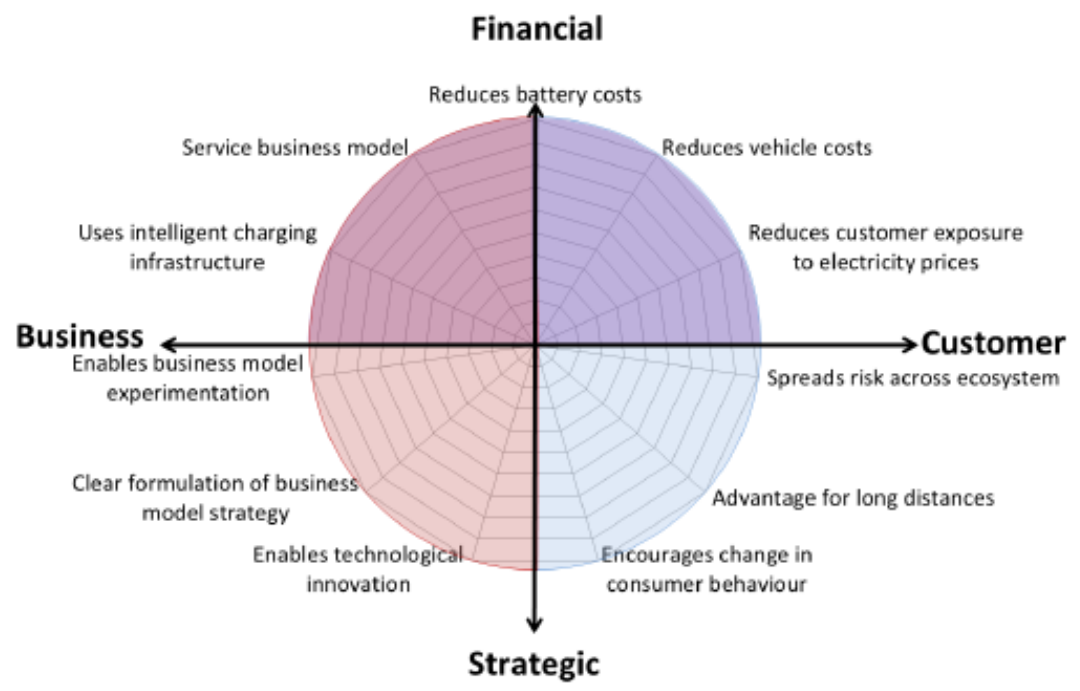

Figure 1: Business model framework with the example of EV commercialization (source: [10]).

\section{Methodology}

The diversity of business models and configurative opportunities require a thorough study. Business ecosystem is not a new expression [3, 4, 10-12], but a business ecosystem in a smart grid is relatively new. The smart grid solution is an undetermined array of the interaction systems due to different incentives across countries [14]. However, one element in common is that the significance of the smart grid infrastructure needs to create value to the value chain [15]. Therefore, this research tries to apply the business model framework developed by Weiller and Neely [10] to investigate the business ecosystem of a smart grid in the rural sub-Saharan Africa.

This research selects a smart grid technology company called Remergy for the case study. Remergy is a Danish company, and exports smart grid solutions to the sub-Saharan countries.

The research firstly investigates the secondary data to address the business and commercialization of a smart grid, and investigates the smart grid market and business in the sub-Saharan Africa. The related literature is to form an understanding of the external circumstances of the smart grid. Then this research adopts Remergy (focal company), Greentech A/S and Greentech Connections 
have contributed to the data with interviews. This will provide an analysis of the business ecosystem of a smart grid in rural sub-Saharan Africa for Remergy.

The data analysis will combine the literature and interviews to create a practical application of an ecosystem based on smart grid business modeling.

\section{Case study and data analysis}

Three factors are analyzed based on the theories by Weiller and Neely (2013), and discussed in order to understand the focal company's business model strategy in the sub-Saharan smart grid ecosystem: organizational, environmental, and global factors.

\subsection{Organizational factors}

The organizational factors assist in identifying the value creation process in the internal business ecosystem. The context of the parameters is determined by the interview with the focal company, Remergy.

Remergy is a collaborative spin-off company from the energy provider TreFor and utility manufacturer System Teknik A/S and it was established at the beginning of 2014. There are seven employees in Denmark including a CEO, who is also the CEO at System Teknik A/S. The main objective for Remergy is to create business models and implementation opportunities for rural micro grids in Africa. Remergy has created one micro grid project in a small rural town called Kayanza, Uganda. At the beginning, the project provided electricity to 68 households, and has expanded to 99 households. Remergy further plan to initiate new projects in other parts of rural Africa.

It is important for focal companies to identify the organizational parameters. It provides information of focal companies' market position and describes the value mechanisms of the smart grid market [10]. It may also identify the possible dimensions of a smart grid that can be introduced to enhance the overall value proposition.

\subsection{Environmental factors}

The experience of the focal company represents the local market and operations in sub-Saharan Africa. However, in order to understand the business ecosystem, it is necessary to observe the environmental factors. The stakeholder relationships of the focal company's in a given market define the environmental factors. These are typical stakeholders at a national level [8]. At the national level, the focal company needs to identify the markets, competition and agencies such as governmental institutions that affect the smart grid solutions.

Markets: in the case of Remergy, the primary market is the rural microgrid due to the expenses of creating rural electrification through distributed grid electricity. The distance between villages makes it impossible to establish advanced grid connections. The focal company has also identified the increasing interests and needs of grid optimizations in sub-Saharan Africa. Remergy may also consider a market such as creating grid independence to public buildings, i.e. hospitals and government buildings, as this market looks promising, 
Table 2: Decoded primary interview with data from Remergy, Greentech and Greentech Connections.

\begin{tabular}{|c|c|}
\hline $\begin{array}{l}\text { Essential business } \\
\text { ecosystem factors }\end{array}$ & Data analysis \\
\hline \multirow{4}{*}{$\begin{array}{l}\text { Organizational } \\
\text { factors/ parameters }\end{array}$} & $\begin{array}{l}\text { - (IV 1) and (IV 3): Direct payment methods (e.g. Mobile payment) } \\
\text { to overcome corruption and scarce finances. } \\
\text { (IV 1): Charging for each consumed kWh ensuring price stability } \\
\text { for consumers. } \\
\text { - (IV 1): Reducing cost of access to electricity for consumers. }\end{array}$ \\
\hline & $\begin{array}{l}\text { - (IV 1): Training of local authorities to ensure proper maintenance. } \\
\text { - } \\
\text { (IV 3): Ensure reliability to the investors in microgrid. } \\
\text { (IV 3): Ensure a business model for the consumers based on } \\
\text { reliable agreements for feed-in, costs of financing etc. }\end{array}$ \\
\hline & $\begin{array}{l}\text { (IV 1): Teach new users to electricity of how to use electricity. } \\
\text { (IV 3): Reduces exposure to unreliable grid. } \\
\text { (IV 3): Reach customer with correct communication based on the } \\
\text { culture of the nation. } \\
\text { (IV 3): Provide a possibility to deliver electricity to consumers in } \\
\text { smaller batches (e.g. }<1 \mathrm{kWh} \text { ) and instead create frequent } \\
\text { payment. }\end{array}$ \\
\hline & $\begin{array}{l}\text { - } \\
\text { (IV 3) and (IV 2): Micro grid solutions prevail as they are cheaper } \\
\text { in rural areas compared to distributing grid electricity. } \\
\text { - } \\
\text { - } \\
\text { (IV 1): Encourage a demand for electricity consumption. }\end{array}$ \\
\hline \multirow{3}{*}{$\begin{array}{l}\text { Environmental } \\
\text { factors }\end{array}$} & $\begin{array}{l}\text { (IV 1) and (IV 2): Customers in rural areas are unaccustomed to } \\
\text { electricity hence availability in these parts triumphs reliability. } \\
\text { (IV 1): Large scale smart grid concepts have been implemented } \\
\text { such as remote monitoring, electricity onsite mobile payment and } \\
\text { demand management. } \\
\text { (IV 3) and (IV 2): Micro grid solutions prevail as they are cheaper } \\
\text { in rural areas compared to distributing grid electricity. } \\
\text { (IV 2): Public buildings are interested in electricity independence } \\
\text { due to unreliable grid. }\end{array}$ \\
\hline & $\begin{array}{l}\text { (IV 2): Some countries in sub-Saharan Africa have rich natural } \\
\text { resources of energy, which they can exchange with neighbors that } \\
\text { has a different source of natural energy. }\end{array}$ \\
\hline & $\begin{array}{l}\text { (IV 1): Credit unions are collaborating with consumers to finance } \\
\text { rural electricity. } \\
\text { (IV 2): Government taxation is not recommended due to political } \\
\text { popularity tendencies. } \\
\text { (IV 3): Include the government in energy projects. } \\
\text { (IV 3): Decentralized energy production may be legally restricted } \\
\text { by the government in certain areas. }\end{array}$ \\
\hline \multirow{3}{*}{ Global factors } & - (IV 1): Create efficient knowledge exchange between nations. \\
\hline & $\begin{array}{l}\text { The procedures and solutions to electricity outages should be the } \\
\text { same in New York as in Africa in terms of fast reaction and } \\
\text { simple solutions. }\end{array}$ \\
\hline & $\begin{array}{l}\text { (IV 1): Electricity demands are increasing. } \\
\text { - } \\
\text { (IV 1): Communicating an awareness of green energy is important } \\
\text { for countries with little experience in electricity consumption. }\end{array}$ \\
\hline
\end{tabular}




\section{Organization Evaluatory Parameters}

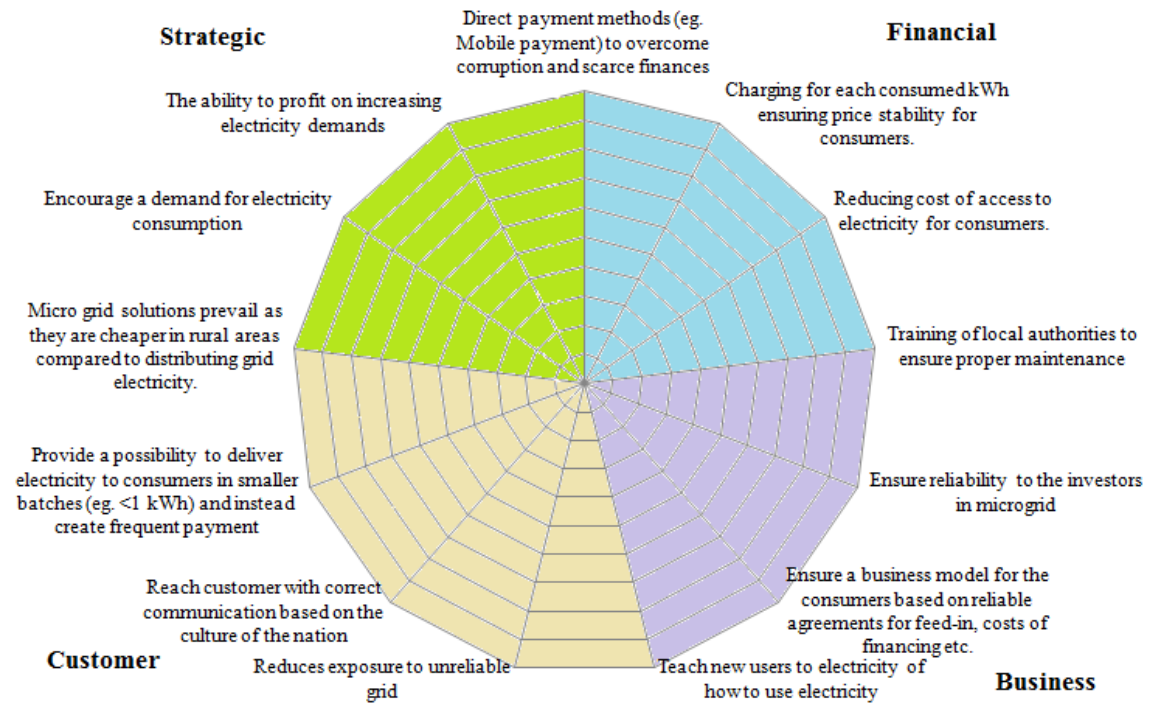

Figure 2: Organizational parameters of the ecosystem based business model in the smart grid.

according to Greentech and Greentech Connections. These markets may be of interest to Remergy to include in their strategies as they have a great willingness to invest, and need of electricity grid independence to overcome reliability issues.

Competition: the competition in sub-Saharan Africa is generally low as the market is relatively new. The interviews with Greentech and Greentech Connections explained that some countries in sub-Saharan Africa have rich natural resources that might offer rich competition and collaboration for the national natural resource in the future.

Agencies: The available finance is typically low for rural electrification investment in sub-Saharan Africa. It is necessary to provide a financial credit agreement by the government for the sustainable development of the smart grid ecosystem, although financing these investments through taxation is not going to generate political approval. However, it is an advantage to include government agencies in the smart grid ecosystem as they possess the financial power and willingness to invest in smart grid development.

\subsection{Global factors}

The global factors present the international dimension of a local smart grid ecosystem. This international presence may be beneficial to the local market in the form of partnerships or alliances. It can also complicate local market intrusion due to global competition.

The case of Remergy states that the business interest to the rural electrification in the sub-Saharan Africa is not only due to the economical reason 
but also to enhance the proficiency by knowledge exchange between projects abroad and in Denmark. This is a typical business model applied in Africa. International companies are willing to establish businesses in Africa to gain knowledge $[16,17]$. It is consequently important to create potential partnerships with international business in a healthy smart grid ecosystem.

\section{Discussion}

The ecosystem based business model in the case study helps researchers and companies explore the strategies of exporting smart grid solutions in a specific market. There are plenty of smart grid solutions, but there are different demands and interests across markets. By investigating the smart grid ecosystem in subSaharan Africa, the focal company, Remergy is able to understand the local market and develop strategies to deliver a complete value proposition to the market. This paper proposes spider-web parameters that can examine the specifications of smart grid solutions to fit the actual market needs. This paper also investigates the interoperability of the players in the smart grid ecosystem. It is the primary approach to understand the business ecosystem. The specificity is elaborately dependent on each market need to involve all the relevant governmental institutions and agencies.

The focal company, Remergy can evaluate the market when accessing a new market or during the market involvement. Figure 3 illustrates the evaluation of Remergy's organizational parameters. The figure shows that Remergy has

\section{Organization Evaluatory Parameters}

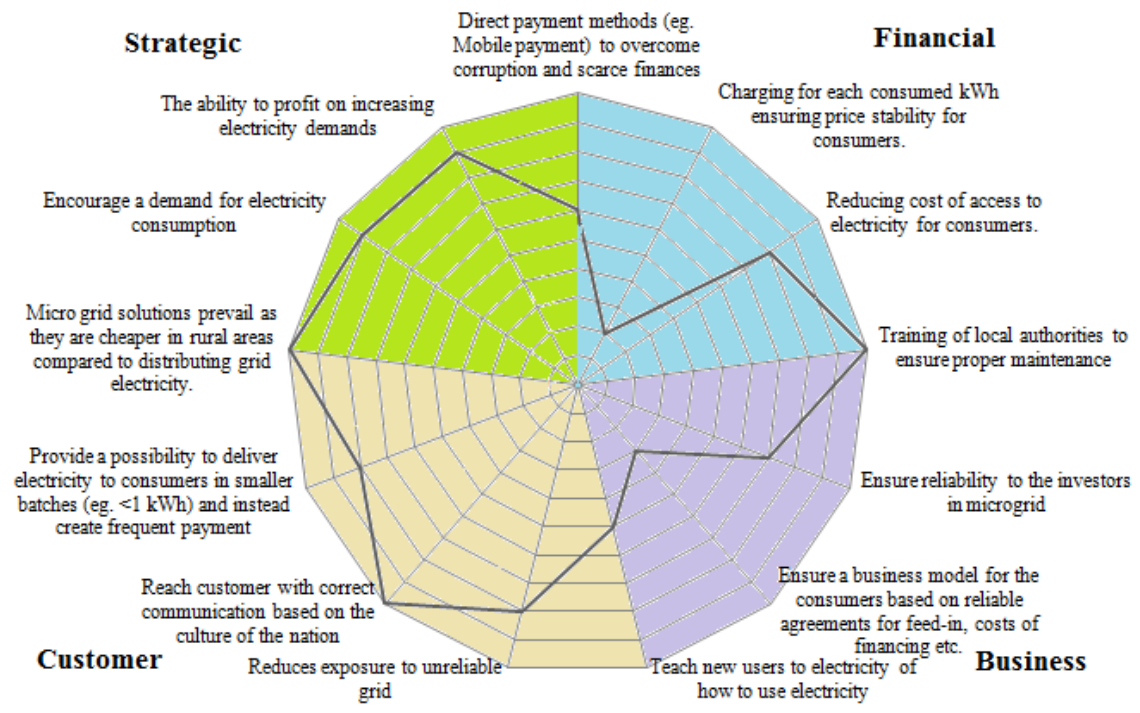

Figure 3: The evaluation of the organizational parameters for the focal company. 


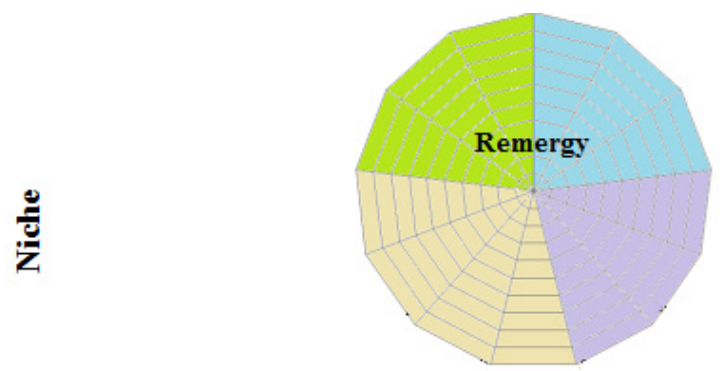

Environmental Factors

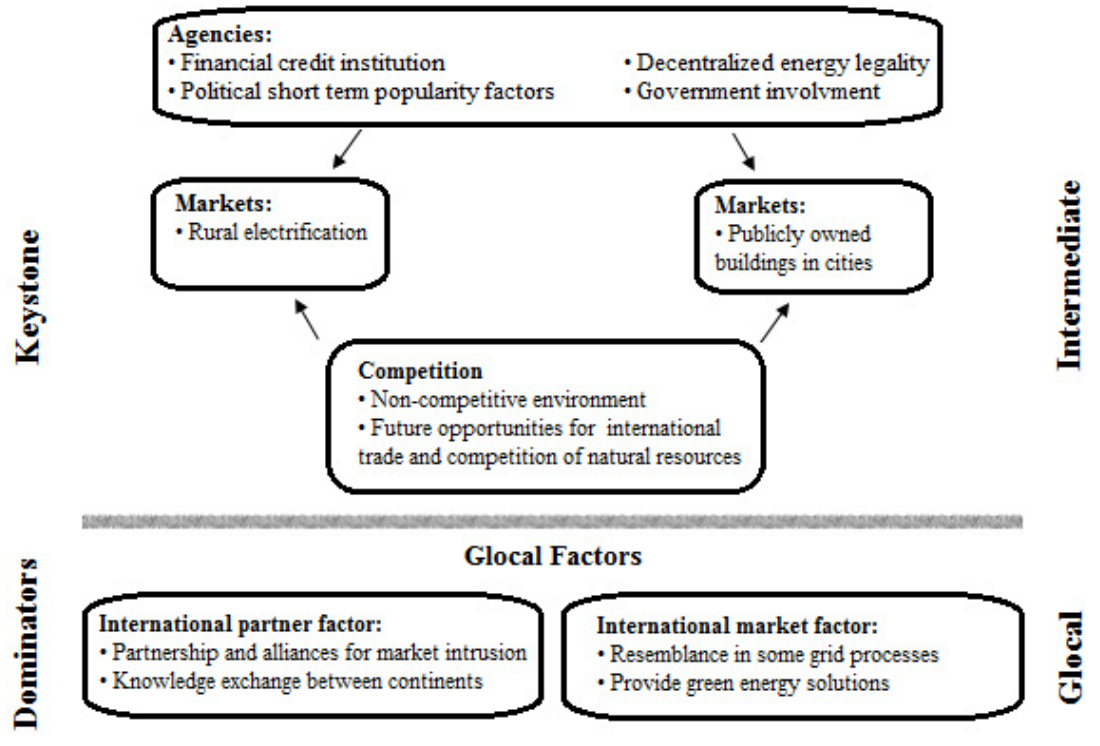

Figure 4: Remergy's business ecosystem based business case analysis.

benefitted from a close market relation with a good understanding of local culture. The company has good scores in strategic and customer parameters. The results reveal that Remergy could improve its value propositions through a better financial model and a business model adoption with a focus on consumer consumption and improved consumer agreements.

In terms of environmental factors, Remergy has only focused on the rural microgrid in sub-Saharan Africa, although there is market potential in the public buildings in cities. Remergy has a low score in the financial dimension of the parameters. This could be addressed by shifting business to the market of public buildings in cities, because this market is potentially invested in due to the governments' high financial power and willingness. Remergy could also initiate a close international partnership with market dominators due to the global factors. This could create greater focus on diverse business models and relieve some financial issues. The evaluation results also reveal that smart grid concepts, such as asset management and real-time payments based on demand 
management, are needed to deliver a complete value proposition, which are the infrastructural components in the rural microgrids.

Across national knowledge exchange in sub-Saharan Africa is a feasible solution to overcome the barriers of local markets. The benefits can be a producthandling experience, accommodating rules and restrictions, market development and less demanding product specifications.

The model developed in this paper provides a possible solution to increase companies' core competence for the higher smart grid market accessibility. The smart grid market demands in sub-Saharan Africa are radically different from developed countries. These demands are closely related to enhancing generation output, reducing transmission loss, and creating a cheaper electricity distribution.

The user interface of these systems may not need to be complex such as the app interfaces and smart metering in developed countries. Further research can be made to investigate the presumption of potential technology leapfrogging in sub-Saharan Africa by the introduction of simplistically interfaced smart grid systems.

\section{Conclusion and further research}

This paper develops a ecosystem based business model for the smart grid solution to expand an understanding of the smart grid eosystem, and explore the connection between smart grid ecosystem and business modelling. This paper also introduces three parameters as companies' strategy dimensions of smart grid soultions. However, the model applied in this paper is generated from the theories of business ecosystems and based on a single case study. Therefore, further research is recommended for the validaition. This paper adopts subSaharan Africa to investigate the smart grid ecosystem due to the minimal viable infrastrucutre of smart grids there. Further research on a different smart grid business ecosystem, such as in developed countries, is suggested to extend the findings, and generalize the model with comparative studies.

\section{References}

[1] International Energy Agency, Worldwide trends in energy use and efficiency: key insights from IEA indicator analysis. www.iea.org. 2008.

[2] Wang, C. and R.G. Prinn, Potential climatic impacts and reliability of very large-scale wind farms. Atmos. Chem. Phys. 10: pp. 2053-2061, 2010.

[3] Moore, J., Predators and Prey: A New Ecology of the Competition. Havard Business Review. 71(3), 1993.

[4] Lansiti, M. and R. Levien, Strategy as Ecology. Harvard Business Review. 82(3): pp. 68-78, 2004.

[5] OECD, ICT Applications for the Smart Grid: Opportunities and Policy Implications, OECD Digital Economy Papers, 2012.

[6] Wolsink, M., The research agenda on social acceptance of distributed generation in smart grids: Renewable as common pool resources. Renewable and Sustainable Energy Reviews. 16(1): pp. 822-835, 2012. 
[7] Xenias, D., Axon, C., Balta-Ozkan, N., Cipcigan, L., Connor, P.M., Davidson, R., Spence, A., Taylor, G. and Whitmarsh, L., Scenarios for the Development of Smart Grids in the UK: Literature Review - Working Paper: www.ukerc.uk, 2014.

[8] Galateanu, E. and S. Avasilcai, Business ecosystems architecture. Fascicle of Management and Technological Engineering. 22(1). pp. 79-84, 2013.

[9] Briscoe, G. and P. De Wilde. Digital Ecosystems: Evolving ServiceOrientated Architectures. in Bio-Inspired Models of Network, Information and Computing Systems. 1st. 2006, 2006.

[10] Weiller, C. and A. Neely, Business model design in an ecosystem context. British Academy of Management Conference, 2013.

[11] Clarysse, B., et al., Creating value in ecosystems: Crossing the chasm between knowledge and business ecosystems. Research Policy. 43(7): pp. 1164-1176, 2014.

[12] Adner, R., Match Your Innovation Strategy to Your Innovation Ecosystem. Harvard Business Review. 84(4): pp. 98-107, 2006.

[13] Chesbrough, H. and R.S. Rosenbloom, The role of the business model in capturing value from innovation: evidence from Xerox Corporation's technology spin-off companies, 2002.

[14] SAIC, S.A.I.C., Smart Grid Around the World.: www.eia.gov, 2011.

[15] Adner, R., The Wide Lens of Innovation - A New strategy for Innovation. New York: Portfolio/Penguin, 2012.

[16] Eberhard, A. and K.N. Gratwick, Independent Power Projects in SubSaharan Africa: Determinants of Success, in Yes Africa can: Success stories from a dynamic continent, The World Bank: www.worldbank.org. pp. 371-399, 2011.

[17] Sinn, M., Cost recovery of isolated microgrids in subSaharan Africa: causalities and prerequisites. Chalmers University of technology, 2014. 